\section{DE DE GRUYTER} OPEN
Journal of Intercultural Management

Vol. 5, No. 2, June 2013, pp. 17-30

DOI 10.2478/joim-2013-0008

Łukasz Sułkowski

Społeczna Akademia Nauk

\title{
A 3D model and typology of organisational culture
}

\begin{abstract}
The proposed model of organisational cultures I used in my research is based on three dichotomous dimensions borrowed from G. Hofstede and other researchers. Although Hofstede proposed studying organisational cultures according to other dimensions of values than in the case of cultures of whole societies, there are numerous authors who think his model is more general and so apply it to organisational cultures too. It seems that three out of five dimensions proposed by Hofstede can become a basis for such a multidimensional model and typology. I am also in favour of this approach, as I believe that three of the dimensions included in Hofstede's model are of a universal character, whether they concern individuals, organisational cultures or social cultures [Sułkowski 2012, pp. 103-118].
\end{abstract}

Keywords: organisational culture, 3D model.

\section{Model of organizational culture}

The model, based on the combination of the dimensions of individualism/ collectivism, power distance and tolerance for uncertainty, sets these three dimensions in the area of fundamental, 'existential' assumptions of individuals and human communities (Table 1). The dimension of individualism/collectivism determines the basic assumption concerning the degree of attachment to a social group [Chatman, Barsade, pp. 423-443]. The dimension of power distance reflects a universal feature of human nature that can be found in all communities in the form of the attitude towards power in a social structure. And finally, the tolerance for uncertainty can be derived from the skill characteristic only of people, which is making plans for the future, together with an intuitive evaluation of the probability of their success. There is no agreement among researchers as to the dimensions of organisational culture, but regardless of their opinions, most of them can see the relationships between the dimensions 
of culture proposed by G. Hofstede, such as individualism vs. collectivism or power distance, and the corporate culture [Aycan, Kanungo, Mendonca, Yu, Deller, Stahl, Kurshid, pp. 192-221].

Table 1. Three dimensions of G. Hofstede, on the level of individuals, organisational culture and social culture.

\begin{tabular}{|l|l|l|l|}
\hline $\begin{array}{l}\text { A dimension of } \\
\text { values }\end{array}$ & Individuals & $\begin{array}{l}\text { Organisational } \\
\text { culture }\end{array}$ & Social culture \\
\hline $\begin{array}{l}\text { Individualism/ } \\
\text { (collectivism }\end{array}$ & $\begin{array}{l}\text { An attitude of an } \\
\text { individual towards } \\
\text { the community. } \\
\text { Attachment to a } \\
\text { group. }\end{array}$ & $\begin{array}{l}\text { Values and norms, } \\
\text { enhancing the status } \\
\text { of individuals or } \\
\text { organisational bonds. }\end{array}$ & $\begin{array}{l}\text { Values and norms, } \\
\text { enhancing the status } \\
\text { of individuals or } \\
\text { social bonds, such as } \\
\text { national, civic. }\end{array}$ \\
\hline $\begin{array}{l}\text { Hierarchisation } \\
\text { - equality } \\
\text { (power distance) }\end{array}$ & $\begin{array}{l}\text { An attitude of } \\
\text { individuals towards } \\
\text { power. } \\
\text { An attitude to } \\
\text { inequality. }\end{array}$ & $\begin{array}{l}\text { Tendency to interpret } \\
\text { organisation in } \\
\text { the categories of } \\
\text { structuralisation and } \\
\text { an increase in the } \\
\text { status differences, or } \\
\text { the opposite. }\end{array}$ & $\begin{array}{l}\text { Striving for the } \\
\text { enhancement of } \\
\text { structuralisation and } \\
\text { an increase in the } \\
\text { status differences, or } \\
\text { the opposite. }\end{array}$ \\
\hline $\begin{array}{l}\text { Tolerance for } \\
\text { uncertainty }\end{array}$ & $\begin{array}{l}\text { Tendency to take } \\
\text { risks and open } \\
\text { planning. } \\
\text { Lower stress related } \\
\text { to planning. }\end{array}$ & $\begin{array}{l}\text { Readiness to develop } \\
\text { and carry less } \\
\text { probable and riskier } \\
\text { variants of plans. }\end{array}$ & $\begin{array}{l}\text { Valuation of the } \\
\text { readiness to take } \\
\text { risks. A lower level of } \\
\text { autonomy and social } \\
\text { frustration caused by } \\
\text { uncertainty. }\end{array}$ \\
\hline
\end{tabular}

Source: Own work.

From among the many dimensions of values, I distinguished three which appear in numerous concepts and research into the influence of culture on organisation (proposed by G. Hofstede, A.A. Trompenaars and C. HampdenTurner, R.D. Lewis, and E. Marx). Together they form consistent configurations of cultures, and are linked with other subsystems (strategy and structure). All values studied largely diversify organisational cultures. The model of organisational culture developed includes as few of the most important diversifying values (dimensions) as possible. Naturally, it is possible to create typologies of other dimensions, including more or less values. Some of the dimensions of values assumed by other concepts were not included in this model at all. It was therefore assumed that they do not concern the level of culture or are of a secondary character. Dimensions distinguished here were recognised as primary, so it is also possible to derive secondary dimensions from them, which were used in other concepts and research. In most cases, secondary dimensions can be derived from the primary with the use of an analysis of the given dimension's semantic contents. 
Hierarchy - equality

Favouring hierarchisation is linked with a belief that people differ, and an organisation reflects this diversity. Thus, organisations should include a number of management levels, and there should be a significant diversification of rights, privileges and benefits among different groups of employees. Special significance should be attached to maintaining discipline and strengthening the authority of power. Hierarchical organisations are dominated by the following attitudes: (1) acceptance of a strong diversity of employees, (2) a preference for elitist thinking, (3) emphasis on the significance of order which gives rise to the structure of power [Cf. Hofstede, 2000, p. 78].

The drive for equality results from the belief that people deserve similar rights, and an organisation is a reflection of such fundamental equality. Thus, organisations should have a flat structure and limit the number of management levels as much as possible. Large diversification of employees' rights, privileges and benefits is unwelcome. Equality gives rise to the following attitudes in organisations: (1) emphasising similarities between employees, (2) favouring egalitarian thinking, (3) orientation towards spontaneity, flexibility of structures and power relationships.

The dimension of hierarchy vs. equality is primal in relation to the dimension of authoritarianism vs. democracy (participation). Authoritarianism means striving for a one-person, unquestionable way of making decisions in an organisation, while democracy means striving for a group (fully participatory) decision-making process. The dimension of hierarchy vs. equality is also primal in relation to the dimension of power centralisation [cf. Harrison, 1972]. In G. Hofstede's concept, the dimension of hierarchy - equality corresponds to the distance in power relations. A large distance means orientation towards hierarchy, while a small distance means equality [Hofstede, 2000].

Individualism - community

Individualism means putting the value of an individual before the interests of a social group. This is related to striving for the freedom of individuals and a belief that individual interests are most important. According to this belief, organisations should focus on the motives and competences of individuals, rather than teams. Fulfilling individual interests can lead to organisational success, as it favours rivalling and competitive attitudes, as well as nonconformist behaviour. Organisation is perceived as a group of individuals who have conflicting interests. S. Lukes emphasises the following basic elements of individualism: human dignity, self-determination and autonomy of individuals, respect for privacy and the possibility to fulfil oneself [Lukes, 1973]. In organisations, individualism is manifested by: (1) treating individual 
freedom as the priority value, (2) the acceptance of individual attempts at independence, (3) a preference for individual interests, (4) rivalling orientation, (5) creating the cult of personality (lone heroes or charismatic leaders).

The community approach (or, in other words, collectivism) is a the belief that the interest of a social group is more important than individual interests, and in the case of organisations it is manifested by the orientation towards group goals, even against individuals, while the preferred attitudes are conformism and collaboration. Emphasising the value of group solidarity, organisations are often perceived as social groups or teams. They achieve success thanks to cooperation and unanimity, which is why individuals should identify themselves with a group. Mostly, it is the teams that are motivated, and only then the individuals. The community approach is manifested by: (1) accepting the idea that the common good is the superior value, (2) emphasising the significance of cooperation in a social group, (3) emphasising the importance of community, (4) orientation towards cooperation and unity in an organisation, (5) creating a cult of group-work.

The community approach is linked with familiarism [Fukuyama, 1997, pp. 77-83]. Familiarism is the strength of relationships between individuals and their families, which is reflected in the organisational sphere. A high level of familiarism supports the development of family entities, but can cause problems when creating organisations managed in a different way (separation of ownership and management). A low level of familiarism more often accompanies the creation of larger, bureaucratic organisations, which limit the significance of family enterprises in business.

A high tolerance for uncertainty - a low tolerance for uncertainty

A high tolerance for uncertainty is related to the readiness to act in situations when there is not enough information. In the case of organisations, this means a tendency to take risks and orientation towards changes [Cf. Sikorski, 1999, pp. 43-55]. Organisations with a high tolerance for uncertainty do not strive to maintain the status quo, but are ready to accept external changes and make transformations ${ }^{1}$. Usually, they adapt to changes in the environment more easily and are flexible. The variants of action and scenarios developed are of a rather indeterminist character. Information deficits and multiple variants are assumed, and rapid changes are treated as opportunities. Greater attention is paid to the organisation's openness, rather than its stability. A high tolerance for uncertainty means:

1 The juxtaposition of change and status quo in an organisation is not invalidated by the approach of 'dynamic stability', which is currently being developed, and which tries to weaken the destructive consequences of rapid internal changes by strengthening employees' sense of stability - E. Abrahamson, Change Without Pain. 
(1) orientation towards changes in the organisation, (2) the acceptance of action in case there is not enough information, (3) a multi-variant game model in the decision-making process [Cf. Hofstede, 2000, p. 197].

A low tolerance for uncertainty combines the striving for the reduction of uncertainty, functioning in the context of low risk, maintenance of the status quo, and an emphasis on the organisation's stabilising role [Cf. Jasiński, pp. 104-107]. The variants of action and scenarios developed are of a determinist character; they assume avoiding risks, a maximum limitation of the information deficit and one-option planning. In most cases, changes are treated as threats. A low tolerance for uncertainty means: (1) orientation towards maintaining the status quo in an organisation, (2) striving for action only when there is all information available, (3) assuming a one-variant, determinist model of decision-making.

Thepresentedprimarydimensionscancorrelatewithothervalues; forexample, to a certain extent hierarchisation conditions formalism or ceremonialism of culture, and the existence of autocratic managementstyles [Gesteland, 2000]. The proposed configuration of primary values can be compared with the proposals contained in several significant projects of intercultural research by R. House, C. Hampdem-Turner, as well as A.A. Trompenaars and G. Hofstede. The GLOBE project by R. House included nine dimensions of culture, influencing leadership in organisations, similar to those described here. They are: collectivism vs. individualism, power distance (corresponding to the dimension of hierarchy), and avoidance of uncertainty vs. tolerance for uncertainty. Other cultural dimensions studied in the GLOBE project are probably of a secondary character in relation to the three assumed primary dimensions. These dimensions include: orientation towards achievements, which is secondary to individualism, equal rights of men and women, probably related to equality, orientation towards the futures vs. presence, probably correlating with the tolerance for uncertainty, family community, which is a special case of the community approach, assertiveness, related to individualism and hierarchisation, and humanist vs. impersonal orientation, correlated with equality.

Trompenaars and Hampden-Turner's model and research distinguish seven elementary dimensions of values [Trompenaars, Hampden-Turner, 1998, pp. 20-21]. Two of them, individualism/collectivism and equality - hierarchy, overlap with the dimensions presented in this monograph. G. Hofstede's research project led to the distinguishing of four dimensions of culture: hierarchy - equality, individualism/collectivism, avoiding the uncertainty and masculinity - femininity [Hofstede, 2000]. The first three dimensions can be found, although in a slightly different form, in the model of organisational culture presented in this work. The dimension of masculinity - femininity does 
not seem completely clear and is defined in different ways (for example, it is defined differently in the GLOBE project). This dimension is secondary, as it correlates with the dimension of hierarchy - equality. The model was developed by Hofstede by adding a fifth dimension called 'Confucian dynamism'.

The values presented above can be jointly found in organisations. Thus, they form certain configurations of values. They constitute a typology of organisational cultures which can be reflected with the use of a threedimensional model.

Figure 1. A three-dimensional typology of organisational culture.

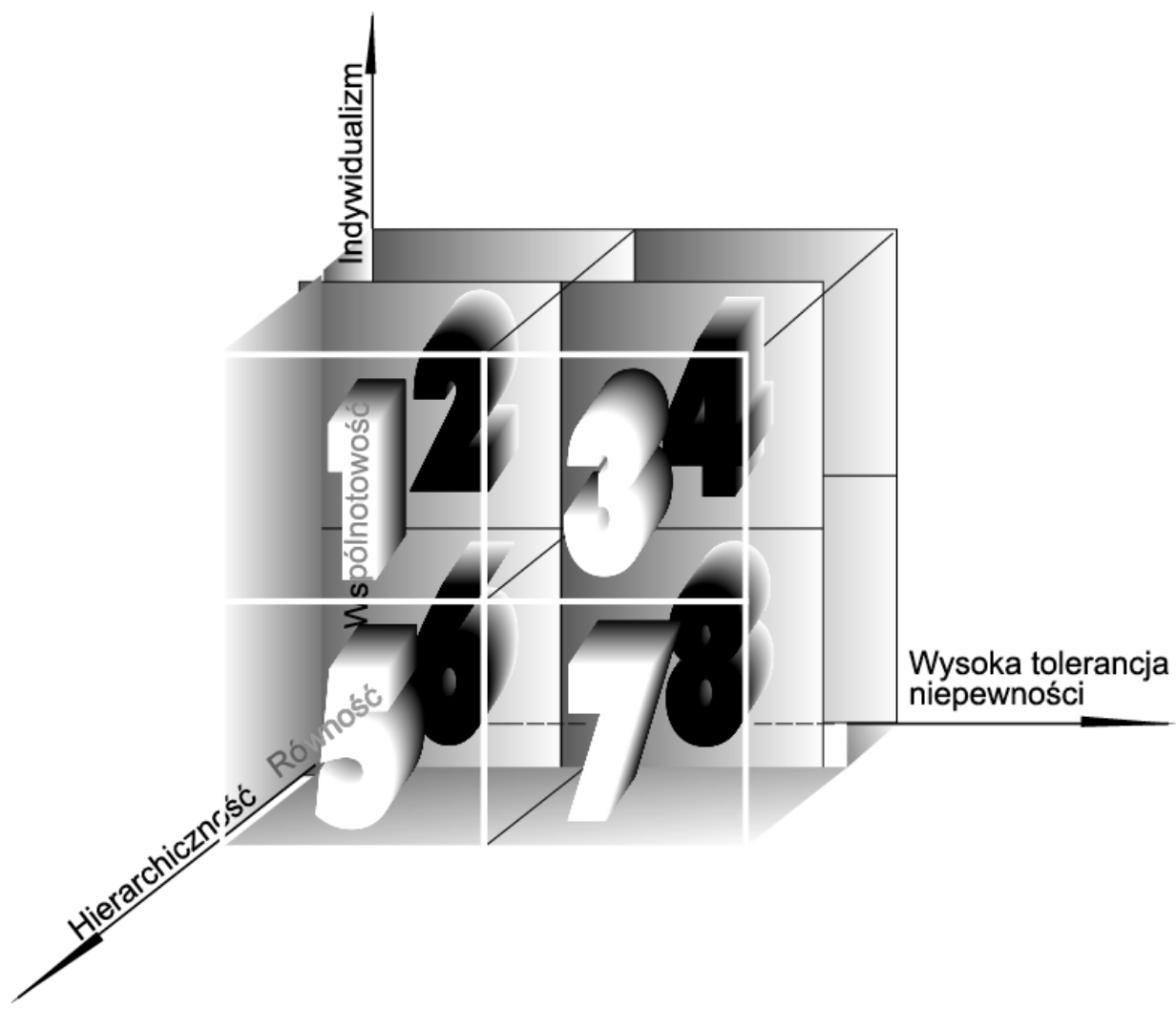

Source: Own work.

\section{Types of organizational culture}

By comparing the three basic dimensions, one can build a classification covering eight types of perfect organisational cultures [Weber, The Methodology of the Social Sciences [M. Weber, The Methodology of the Social Sciences]. 
Type 1 - Organisation of ossified management

A configuration combining individualism, hierarchisation and a low tolerance for uncertainty: The values of the organisation justify the fact that the managerial positions in the structure are occupied by privileged people. The significance of managers is emphasised, and myths are created about them (especially about those on higher levels). They are made organisational heroes. Emphasis is put on stability and discipline, which is supported by an autocratic management style that, on lower levels, often takes the form of despotism, and paternalism on higher levels. There is formalism in the organisation, assuming a ceremonial and ritual form, and covering of internal communications. The centralised information flow is fully consistent with the organisational structure and has the form of a pyramid (messages come from top to bottom). Type 1 is a conservative, traditional organisation, in the case of which changes take places as a response to the pressure of the environment and are of a topdown character. A moderately competitive orientation prevails, as conflicts are suppressed by formalism, while personal changes are delayed because of conservatism. Power is strong and concentrated at the top of the hierarchy. There is no familism in such organisations, all indications of nepotism and cliques are officially and unofficially condemned. There is no atmosphere that would support the creation of subcultures, much less counter-cultures.

Type 1 organisations are characterised by a complex, formalised organisational structure. Strategy can be formally extended and documented, but it is quite reactive and inflexible. Usually, the orientation towards operational activities prevails, although strategic orientation is also possible. However, in such cases strategies only include one variant and are not very detailed. Type 1 organisations are adjusted to functioning in stable sectors, which develop slowly and require the centralisation of activities and specialisation (because of the economy of scale). In the case of rapid changes in the environment, they can be ineffective.

Type 2 - Organisation of personal benefits

Orientation towards individualism, equality and a low tolerance for uncertainty: Values indicate that all employees have a right to decide and benefit from staying in the organisation. The significance of the employees' ethos is often emphasised. There is a common belief that ordinary workers are exploited by those in charge. Mythology is of an unofficial character and is created based on stories about opportunities the organisation missed because of the managers. Managerial positions are treated with mistrust and envy. On the other hand, promotions are perceived in terms of power usurpation. Social relationships in such organisations are reminiscent of a war between everybody, 
where employees have professional ambitions but others bring them down to mediocrity. Managers have limited power and a sense that their positions are under constant threat. This is why, believing that the autocratic management style is superior, they are forced to play a complex game of manipulation and negotiation between different organisational actors. The level of formalism is moderate. Communication is not largely centralised and formalised. The information flow is open, which gives employees access to the managers. To sum up, it can be said that Type 2 is to a certain extent similar to Type 1 - it is a conservative organisation, which makes changes as a response to the pressure of the environment of a top-down character; also the level of familism is rather low. However, in organisations of this type, two hostile counter-cultures are often created, including performance workers and the management. Such organisations often have a flattened organisational structure. Strategy is usually limited, rather reactive and oriented towards operational activities. This type can be most often found in stable economic sectors which change slowly. In the case of this culture, changes are unwelcome.

Type 3 - Organisation of transformational leadership

Orientation towards individualism, hierarchisation and a high tolerance for uncertainty: The organisation's values focus on charismatic leadership. Autocratic management styles prevail. The significance of leaders is emphasised and myths about them are created. They are made organisational heroes. Organisations of this type are not highly formalised - leaders contact all levels of the organisation, using both official and unofficial channels. The information flow remains open (there are no barriers), although communication is aimed at the main link - the leader. Type 3 organisations are oriented towards changes that are quickly implemented by transformational leaders, and so the values include creativity and expansiveness. A moderately competitive orientation is typical, although conflicts are suppressed by leadership. Power is strong and concentrated at the top of the hierarchy, while organisation is supposed to be cohesive and centralised. In this case, the level of familism is relatively low, nepotism and cliques are not tolerated. No subcultures or counter-cultures can be created.

In this type, orientation towards strategic activities usually prevails - the vision of the leader is the basis for strategy. Organisations of this type usually allow introduction of quick, deep organisational changes, although decisions about these are made top-down. Type 3 can be most often found in dynamic economic sectors, which rapidly develop or undergo transformations. 
Type 4 - Organisation of adventurers

Orientation towards individualism, equality and a high tolerance for uncertainty: Organisational values focus on the rivalry between individuals in the context of a 'free internal labour market'. One of the values is 'change leading to the organisation's development'. The leaders have strong personalities and similar rights. Organisational mythology emphasises the role of individuality, autonomy and creativity. Participatory management styles dominate. Organisations are quite informal, and internal communication is fully open and dispersed. Motives and concepts of changes are created by individuals. Employees are oriented towards rivalry, both within and between teams. Power is distributed among individuals who manage their teams. The level of familism is relatively low. Subcultures are formed around individualities, but they are not very strong, are of a fluid character and do not transform into counter-cultures.

Type 4 organisations often have a flattened and informal organisational structure, while strategy is multi-variant and expansive. Orientation towards strategic activities prevails. Changes are implemented quickly, in an anticipatory way, and can be initiated by many centres (they are decentralised), which allows for deep transformation, strongly involving employees. Problems and complications result from the multiplicity and changeability of influences, which may lead to anarchy. Type 4 is most often found in dynamic, rapidly developing and dispersed economic sectors (a lower level of capital concentration).

Type 5 - Organisation - stabiliser

Orientation towards community, hierarchisation and a low tolerance for uncertainty: Values of the organisation justify the maintenance of status quo. Mythology is created around the 'golden time' of no changes, full security and stability, both for managers and performance workers. The value and tradition. Organisational heroes are long-standing managers who strive for the maintenance of stability. Autocratic management style, close to paternalism, prevails. The level of formality is high, and often takes a ceremonial, or even ritual form. Excessive bureaucracy is common. Communication is formalised and centralised. Conservatism dominates - changes are implemented slowly and are coerced by the environment. Decisions about changes are made topdown, and are often resisted by employees at lower levels. There is a moderate orientation towards cooperation. On the one hand, power is concentrated at the top of the hierarchy, while on the other, there is strong influence from employee lobbies (unions, councils etc) and sometimes of other interested parties (for example political). Familism is moderate, nepotism is officially condemned, but unofficially it is present in the organisation. Even cliques are 
common. Strong subcultures appear, and sometimes counter-cultures, usually based on the juxtaposition of performance workers with the management, and the antagonisms between different employee groups.

Type5organisationsarecharacterisedbyacomplex, formalisedorganisational structure. Strategy is one-variant and highly reactive. Orientation towards operational activities prevails. Special emphasis is put on maintaining the cohesion of the organisation. It is difficult to introduce changes, and they are of a reactive character. Type 5 is most often found in stable, slowly changing economic sectors, having a strong employee lobby group.

Type 6 - Organisation - a conservative community

Orientation towards the community, equality and a low tolerance for uncertainty: Organisational values are oriented towards the employees' sense of security. Similarly to type 5, the value is tradition, but in this case organisational heroes are employees who strive for the social security of employees (for example, leaders of trade unions) and performance workers who have a sense of injustice and feel undervalued. Participative management styles dominate, sometimes using populist motifs. Decisions are usually made jointly. Professional career paths are open, and there is a fairly high rotation of managerial positions. Communication is informal, open and decentralised. Type 6 includes highly conservative organisations, which implement changes very slowly and only as a result of pressure from the environment. Decisions about changes can be top-down or made as an initiative of one of the power centres. Organisations are oriented towards cooperation and satisfying the needs of numerous organisational groups. Power is distributed among different centres of influence - employees and managers, individual departments, branches, units and sections. The level of familism is high, individual centres form cliques and can support the promotion of family members. Strong subcultures, or even counter-cultures appear.

Type 6 organisations are characterised by a flattened, decentralised organisational structure. Strategy is usually limited and reactive, orientation towards operational activities prevails. It is very difficult to introduce changes, as they are hindered by dispersed power. Type 6 can be most often found in stable, slowly changing economic sectors.

Type 7 - Organisation of thriving teams

Orientation towards the community, hierarchisation and a high tolerance for uncertainty: This type of organisation's values are oriented towards organised, dynamic teams. Myths concern the quick, bold, successful actions of teams (organisational units). The organisation's heroes are the leaders who know 
how to make use of teamwork. Participative management styles dominate. Communication is informal, decentralised and completely open. The dominant value is change. Type 7 includes dynamic organisations, oriented towards quick changes, often of an anticipative character. Changes can be planned top-down or result from grassroots initiatives. There is a moderate orientation towards cooperation. On the one hand, power is concentrated at the top of the hierarchy, but on the other, the influence of the teams of employees can be very strong. The level of familism is quite high, and there are clear cliques. Strong subcultures, or even counter-cultures appear, but they are eliminated by managers.

Type 7 organisations are characterised by a fairly extended organisational structure, which doesn't translate into limitations to communication. Strategic orientation prevails, but strategy itself is understood as a multi-variant game. There are no complex, long-term planning procedures. Type 7 can be most often found in young, dynamic, rapidly developing economic sectors.

Type 8 - Organisation - a dynamic community

Orientation towards the community, equality and a high tolerance for uncertainty: The organisation's values are oriented towards aflexible community. Mythology is created around spontaneous, bold activities and decisions made by teams (groups of employees). Organisational heroes are team members who take part in successful activities. Participatory management styles dominate, often taking the form of democracy. The level of formalism in the organisation is low. Communication is informal, decentralised and completely open. The values include community and change. Type 8 organisations are dynamic and oriented towards quick changes which anticipate trends. Changes are often the results of grassroots initiatives. A strong orientation towards cooperation is typical of these organisations. Power is distributed among teams of employees. In most cases, the level of familism is high and there are clear cliques, although no strong subcultures are created, as they are quickly eliminated. There are no counter-cultures.

Type 8 organisations are characterised by a flattened and decentralised organisational structure. Strategy is complex and quite expansive. An orientation towards strategic activities prevails, which are understood as multi-variant organisational games. Orientation towards operational activities is also possible, which results from the sense of a lack of possibilities to create a strategy in such a changeable sector. This type of organisational culture allows quick, anticipative and grassroots organisational changes. Type 8 is most often found in dynamic, quickly developing economic sectors.

It is important to note that the values studied for organisational indicators are not dependent only on culture. The type of a strategy, structure or a degree 
of familism can be also conditioned by the type of ownership, market position or the enterprise's financial situation, which is why the descriptions of the types of organisational culture have to be treated as conditioned by many factors [Sułkowski, Wieloznaczność kultury organizacyjnej, 2012].

\section{Consequences for HRM}

As one can see in the presented description of culture types, the configuration of values has an influence on most areas of organisation management, including the methods of managing human resources. To put it simply, types of armies have been used to describe the individual types of organisational cultures (Table 2).

Type 1 - Army of knights

Type 2 - Mercenaries

Type 3 - Conquistador army

Type 4 - Levy in mass

Type 5 - Army of janissaries

Type 6 - Revolutionaries

Type 7 - Duke's squad

Type 8 - Partisans

Table. 2. Types of organisational cultures and example ways of managing human resources.

\begin{tabular}{|c|c|c|c|}
\hline $\begin{array}{c}\text { 1. Army of } \\
\text { knights }\end{array}$ & $\begin{array}{c}\text { Recruitment } \\
\text { individuals, only the } \\
\text { management. }\end{array}$ & $\begin{array}{c}\text { Managers reward } \\
\text { individual employees. }\end{array}$ & $\begin{array}{c}\text { Training of the } \\
\text { management, } \\
\text { concerning detailed } \\
\text { issues. }\end{array}$ \\
\hline 2. Mercenaries & $\begin{array}{c}\text { Recruiting qualified and } \\
\text { strongly competitive } \\
\text { individuals. }\end{array}$ & $\begin{array}{c}\text { Mechanisms of } \\
\text { rewarding the best } \\
\text { (rules of awarding } \\
\text { bonuses) }\end{array}$ & $\begin{array}{c}\text { Self-improvement, } \\
\text { limited internal } \\
\text { training concerning } \\
\text { detailed issues. }\end{array}$ \\
\hline army & $\begin{array}{c}\text { A leader looks for } \\
\text { potential supporters } \\
\text { - determination and } \\
\text { motivation to work are } \\
\text { the key elements. }\end{array}$ & $\begin{array}{c}\text { Involvement and } \\
\text { loyalty to the leader are } \\
\text { rewarded. }\end{array}$ & $\begin{array}{c}\text { Education is a process } \\
\text { of integration around } \\
\text { the leader. }\end{array}$ \\
\hline 4. Levy in mass & $\begin{array}{c}\text { Self-recruitment } \\
\text { most of those who are }\end{array}$ & $\begin{array}{c}\text { Mechanisms of } \\
\text { rewarding and, in } \\
\text { consequence, selection } \\
\text { (the weakest do not } \\
\text { gain). }\end{array}$ & $\begin{array}{c}\text { Self-education, limited } \\
\text { specialist training. }\end{array}$ \\
\hline
\end{tabular}




\begin{tabular}{|c|c|c|c|}
\hline $\begin{array}{c}\text { 5. Army of } \\
\text { janissaries }\end{array}$ & $\begin{array}{c}\text { Recruits are loyal and } \\
\text { susceptible to discipline. }\end{array}$ & $\begin{array}{c}\text { Rewards follow } \\
\text { bureaucratic } \\
\text { regulations. }\end{array}$ & $\begin{array}{c}\text { Strong indoctrination } \\
\text { trainings, which } \\
\text { enhance loyalty. }\end{array}$ \\
\hline $\begin{array}{c}\text { Revolutionists } \\
\text { to missionary activities. }\end{array}$ & $\begin{array}{c}\text { Recruits are susceptible } \\
\text { consequence, selection } \\
\text { (the weakest do not } \\
\text { gain). }\end{array}$ & $\begin{array}{c}\text { Indoctrination } \\
\text { training, network } \\
\text { mechanisms of } \\
\text { promotion. }\end{array}$ \\
\hline 7. Duke's squad & $\begin{array}{c}\text { Recruits want to } \\
\text { function in a strong and } \\
\text { loyal team. }\end{array}$ & $\begin{array}{c}\text { Involvement and } \\
\text { loyalty to the group are } \\
\text { rewarded. }\end{array}$ & $\begin{array}{c}\text { Integration training, } \\
\text { focused on the } \\
\text { management. }\end{array}$ \\
\hline $\begin{array}{c}\text { People who have ideas } \\
\text { and want to implement } \\
\text { them in a team are } \\
\text { recruited. }\end{array}$ & $\begin{array}{c}\text { Involvement and loyalty } \\
\text { to the group and ideas } \\
\text { are rewarded. }\end{array}$ & $\begin{array}{c}\text { Integration and } \\
\text { indoctrination training } \\
\text { include managers and } \\
\text { specialists. }\end{array}$ \\
\hline
\end{tabular}

Source: Own work.

Naturally, the influence of organisational culture on the human resources function as presented here is slightly exaggerated, and in some cases, largely simplified. The patterns of human resources management, resulting from the configuration of organisational values, can be different, but there is no doubt that the type of organisational culture has a significant influence on the system of managing human resources. Of course, organisational culture is one of the reasons for the creation of human resources management, but other variables, such as the specificity of a given activity and enterprise, are also important. From the point of view of managers, there is a need for awareness, as to what values function in the organisation and what their influence on human resources management is. The selection, motivation and education of employees, oriented towards the reproduction of the same type of organisational culture, can be limited by the changes and effectiveness of the organisation.

The presented model of organisational culture and the typology of organisational cultures resulting from it are mostly a theoretical concept and require in-depth verification by empirical research in the future. What is needed now is research into an organisation's members' change of value systems [Sułkowski, 2002], together with an analysis of the type of human resources management, strategy, structure and power in the given organisation.

\section{Bibliography:}

Aycan, Z., Kanungo, R., Mendonca, M., Yu, K., Deller, J., Stahl, G., Kurshid, A., Impact of Culture on Human Resource Management Practices: A 10-Country Comparison, Applied Psychology, 2000, 49: 192-221.

Chatman, J.A., Barsade, S.G., Personality, Organizational Culture, and Cooperation: Evidence from a Business Simulation, Administrative Science Quarterly, Vol. 40, No. 3 (Sep., 1995), pp. 423-443. 
Fukuyama, F., Zaufanie: kapitał społeczny a droga do dobrobytu, translated from English by Anna and Leszek Śliwa, ed. PWN, Warszawa - Wrocław 1997.

Gesteland, R.R., Różnice kulturowe, a zachowania w biznesie, PWN, Warszawa 2000.

Harrison, R., Understanding Your Organization's Character, Harvard Business Review, 1972, May-June.

Hofstede, G., Kultury i organizacje. Zaprogramowanie umysłu, PWE, Warszawa 2000.

Hofstede, G., Kultury i organizacje. Zaprogramowanie umysłu, PWE, Warszawa 2000.

Hofstede, G., Kultury i organizacje. Zaprogramowanie umysłu, PWE, Warszawa 2000.

Hofstede, G., Kultury i organizacje. Zaprogramowanie umysłu, PWE, Warszawa 2000.

Jasiński, Z., Czynniki warunkujące gotowość pracowników do zmian w organizacji.

Lukes, S., Individualism, Oxford University Press, Oxford 1973.

Sikorski, C., Zachowania ludzi w organizacji, Warszawa, Wydaw. Naukowe PWN, 1999.

Sułkowski, Ł., Czy kultury organizacyjne zmierzaja do unifikacji, „Zarządzanie Zasobami Ludzkimi”, nr 3-4, 2002.

Sułkowski, Ł., Kulturowe procesy zarzq̨dzania, Difin, Warszawa 2012.

Sułkowski, Ł., Wieloznaczność kultury organizacyjnej, „Przedsiębiorczość i Zarządzanie. Szanse i zagrożenia rozwoju przedsiębiorczości” red. J. Woroniecki, Ł. Prysiński, tom XIII, Zeszyt 12, 2012.

Trompenaars, A.A., Hampden-Turner, C., Siedem kultur kapitalizmu. USA, Japonia, Niemcy, Wielka Brytania, Szwecja, Holandia, Dom Wydawniczy ABC, Warszawa 1998. Weber, M., The Methodology of the Social Sciences. 